\title{
Australian Journal of \\ Crop Science \\ Biocidal potential of some organic by-products on sanitary and physiological quality of red and white fava beans seeds
}

\section{Maria Josilene de Oliveira Sousa ${ }^{1}$, Fernandes Antonio de Almeida ${ }^{1}$, Maria Lucia Tiburtino Leite ${ }^{2}$, Wéverson Lima Fonseca ${ }^{3 *}$, Kilson Pinheiro Lopes ${ }^{1}$, Camile Dutra Lourenço Gomes ${ }^{1}$, Erik Gomes Sampaio ${ }^{1}$, Elidayane da Nobrega Santos ${ }^{1}$, Ancélio Ricardo de Oliveira Gondim ${ }^{1}$}

\author{
${ }^{1}$ Center for Agro-Food Science and Technology, Federal University of Campina Grande, Campina Grande, Paraiba, \\ Brazil \\ ${ }^{2}$ Department of Agriculture, Federal University of Piauí, Bom Jesus, Piauí, Brazil \\ ${ }^{3}$ Department of Crop Production, Federal University of Ceará, Fortaleza, Ceará, Brazil
}

*Corresponding author: weverson.limaf@gmail.com

Abstract

\begin{abstract}
Fava bean (Phaseolus lunatus L.), is a rustic species and has great adaptability to arid regions of Brazil and stands out for its social importance and high levels of protein. Even so, the culture presents low productivity due to several factors, such as the quality of the seed. In this sense, the objective of this study was to evaluate the fungitoxic action of organic products, namely vinasse, cassava wastewater and agave extract, isolated and mixed, for treatment of beans seeds. The experimental design was completely randomized in factorial $8 \times 2$ (eight byproducts $x$ two seed groups) with five replications. The seeds were evaluated for hysiological and sanitary quality, properly incubated in Petri plates on a triple layer of filter paper, sterilized and moistened with distilled water, where the assessments of the incidence of plant pathogens were performed after 7 days of incubation. Through the results, it is observed that the seeds of red fava bean were the most tolerant to organic products, without compromising the physiological quality. In general, the byproducts have significantly reduced the incidence of fungi identified in red and white fava bean.
\end{abstract}

Keywords: Phaseolus lunatus, seed sanity, allelopathy.

Abbreviations: CCTA_Center for Agro-Food Science and Technology; UFCG_Federal University of Campina Grande, T1_terile distilled water (negative control); T2_Captan ${ }^{\circledR}$ equivalent to $1.0 \mathrm{~g} / \mathrm{kg}$ of seeds (positive control); T3_Extract of Agave; T4_Cassava wastewater; T5_Vinasse; T6_Agave extract + cassava wastewater; T7_Agave extract + vinasse; T8_Cassava wastewater + vinasse; RF__Red fava; WF_White fava; G_Germination; FC_First count; RL_Radicle Length; IVG_Germination Velocity Index; GCS_Germination Speed Index; RF_For seeds of Red Fava; WF_White Fava.

\section{Introduction}

Fava bean (Phaseolus lunatus L.) is one of the most exploited legumes adapted and nutritious in Brazil, with the planted area of 25,543 ha and average yield of productivity of $339 \mathrm{~kg}$ ha $^{-1}$ (Ibge, 2013). Its economic and social importance has aroused greater interest in family farming (Lopes et al., 2010), which makes it an alternative source of income and livelihood of the population of the Brazilian Northeast, which is responsible for $98.24 \%$ of the national production (Ibge, 2013; Penha, 2014).

The state of Paraíba, stands with productivity over $35.8 \%$ of the national production, being cultivated in almost all the microregions of the state with a planted area of 8,254 ha (Ibge, 2017). However, the productivity of the region is below the reality of Rio Grande do Sul, which is a reference in the national scenario, with yield of $2,154 \mathrm{~kg} \mathrm{ha}^{-1}$, resulting from more adequate management techniques for the culture (Ibge, 2017).

Among the challenges to the fava bean culture is the sanitary quality of the seeds, by the presence of pathogens, such as: Fusarium solani, Aspergillus, Penicillium notatum, Phoma sp. and Rhizopus stolonifer, Botrytis sp., which compromise the physiological quality of the culture, due to the conditions of production and storage (Gomes et al., 2016).

Thus, the treatment of seeds constitutes one of the most important measures in agriculture, by the simplicity of implementation, low relative cost and effectiveness under various agronomic aspects (Flávio et al., 2014). However, the most common practice, relates to the use of chemical pesticides, however, there is no record of products recommended for the crop of beans, which in many cases, have to count on the use of products applied in $P$. vulgaris. Some natural active principles which have been used and marketed in Brazil, as oil of Geranium, Natualho, Pironat, Rotenat and Natuneem, all from plant species as the Pelargonium graveolens, Allium sativum, pyroligneous acid, Ateleia glazioviana and Azadirachta indica, with biocidal potential to the most varied pathogenic microorganisms (Lopes et al., 2005; Franke, 2005).

In this sense, the objective of this work was to evaluate the efficiency of organic byproducts such as vinasse, cassava wastewater and agave extract in reducing the incidence of 
fungi present in fava bean seeds, and possible interference in the physiological activities.

\section{Results and Discussion}

\section{Effect of organic by-products on the sanitary quality of seeds of fava}

Upon analyzing the results concerning the composition and the incidence of fungi in seeds of fava bean, the following species were observed and identified: Aspergillus niger, $A$. flavus, Penicillium sp., $P$. variable and Fusarium verticillioides (Table 2 and 3), as well as already observed by Araújo et al. (2009) studying the sanitary quality of seeds of d'anta fava beans.

Through the results of the analysis of variance presented in Table 2, there was a significant effect $(p<0.01)$ of the interaction between the accessions of fava bean and the organic byproducts in the management of the fungi present in the fava beans.

The organic byproducts applied on the fava beans, showed variations among the different species of fungi. Regarding the incidence of the species Aspergillus niger in red fava bean seed, with the exception of the treatment T8 (cassava wastewater + vinasse), all treatments statistically differed from the negative control (water). Among the treatments with best neutralization in relation to the control, T6 stands out (agave + cassava wastewater) with a reduction of $98.60 \%$, differing including from the treatment T2 (Captan) which reduced $92.60 \%$, in addition to T3 (agave) which obtained $85.98 \%$ reduction in the incidence, with the result statistically equal to $T 2$.

As for the white fava bean seeds, in addition to the treatment T8, there was also no significant effect for the treatment T5 (vinasse), demonstrating that these treatments had no effect on the reduction of the growth of the species (Table 3). The efficiency of chemical treatment observed in this study, is possibly related to the fact that the product used to be considered a broad spectrum of action in relation to the group of fungi found in the fava bean seeds. While the positive response of potentiality of efficiency of cassava wastewater+ agave extract, may be associated with the presence of the secondary metabolite of class of glycosides and hecogenin, respectively, with antimicrobial and bioinsecticide property, already observed in other studies (Santos et al., 2009; Fonseca et al., 2016; Fonseca et al., 2018).

For the fungus Aspergillus flavus (Table 3), the greatest efficiency of products applied on the variety of red fava bean, was observed with a reduction of $100 \%$ for treatments T5 (vinasse) and T6 (agave + cassava wastewater). However, the remaining treatments showed reduction between $44.68 \%$ T4 (cassava wastewater) and greater than $68.10 \%$ with the treatments T3 (agave); T7 (Agave + vinasse) and T8 (cassava wastewater + vinasse). The application of the treatments in seeds of fava white bean, maintained the efficiency of the by-products for treatments T3 (agave) and T6 (agave + cassava wastewater), with results statistically equal to T2 (chemical), demonstrating that the by-products have the same efficiency when compared to the application between the fava bean varieties (Table 3 ).

Among the products used in this study, the vinasse presents a high concentration of nutrients, which makes it, an alternative source in the fertilization, at the same time, promotes the induction of resistance against biotic and abiotic damages in the plants (Paulino et al., 2011). Whereas for the agave extract, the presence of secondary metabolites such as: steroidal saponins (Hart et al., 2007), tannins, alkaloids and coumarins (Morais et al., 2010), express different properties: antiulcer, anti-helminthic, larvicide and antifungal effect (Botura et al., 2013; Santos et al., 2009), which leverages it as a viable alternative in family farming.

In the accessions of fava and white fava beans, in the presence of the species Penicillium sp., with the exception of T8 (cassava wastewater + vinasse), when applied to the seeds of red fava bean, the others were significantly equal to T2 (chemical), preventing the emergence of the pathogen (Table 3). Among the byproducts, the presence of organic matter and total sugars in the vinasse, promotes the biological activity of the soil, which favors potential antagonistic microorganisms, in addition to promoting formation of organic substances, such as volatile fatty acids, which may present antimicrobial action (Tenório et al., 2000; Leite et al., 2019).

These results highlight the importance of seed treatment with products of this nature, particularly in view of the genera Penicillium sp. and Aspergillus sp. considered fungi of storages, being responsible for a reduction in seed vigor, preventing its germination and death of the embryo, also have the ability to deteriorate grains and seeds, as well as, can even produce mycotoxins (Riverberi et al., 2010).

For a variety of red fava bean the lower rate of incidence of the fungus Penicillium variable was observed in treatments T3 (agave), T5 (vinasse), T6 (agave + cassava wastewater), T7 (agave + vinasse) and T8 (cassava wastewater + vinasse), with a reduction of $100 \%$, proving the efficiency of these organic products in pathogen control, however, when treated with cassava wastewater (T4) and the chemical product (T2), even favoring the emergence of $P$. variable, promoted reduction higher than $90.24 \%$ in relation to the negative control (T1). Whereas for the access of white fava bean, all treatments showed efficiency when compared to the negative control, highlighting just three products: T5 (vinasse), T6 (agave + cassava wastewater) and T7 (agave + vinasse), which did not differ from T2 (chemical), which promoted a reduction of $100 \%$. The incidence of Fusarium verticillioides in variety of red fava bean, had a marked reduction (71.43\%), in treatments T3 (agave); T6 (agave + cassava wastewater), T7 (agave + vinasse) and T8 (cassava wastewater + vinasse), did not differ statistically from the T2 (chemical). As for the seeds of white fava bean, all treatments showed to be efficient, where a smaller reduction was observed for T4 (cassava wastewater) with $62.22 \%$, and for the others, reaching a reduction of $100 \%$ of the pathogen. It was also observed, little variation among the efficiency of treatments comparing between the varieties of fava beans. The species of the genus Fusarium in some cultures, in particular $F$. verticilioides in the culture of corn (Zea mays), considered as one of the main problems in seed germination, can be easily transmitted (Parsa et al., 2016). In this sense, it is possible that the fava beans seeds have been contaminated in the own production area, since the small producers have the habit of intercropped planting among different species of culture, including corn with fava bean. Therefore, studies using plant extracts as an alternative for the management of the sanitary quality of 
Table 1. Physicochemical analysis of organic by-products used in the treatment of bean seeds Pombal, 2018.

\begin{tabular}{|c|c|c|c|}
\hline Physicochemical-parameters & Cassava & Agave extract & Vinasse \\
\hline Ashes & $0.17 \% \pm 0.01$ & $0.60 \% \pm 0.03$ & $1.11 \% \pm 0.09$ \\
\hline Proteins & $0.65 \% \pm 0.0$ & $1.60 \% \pm 0.13$ & $1.02 \% \pm 0.12$ \\
\hline Total sugars & $1.07 \% \pm 0.09$ & $2.43 \% \pm 0.18$ & - \\
\hline Phenolic & $275.25 \mu \mathrm{g} / \mathrm{g} \pm 0.9$ & $2403.38 \mu \mathrm{g} / \mathrm{g} \pm 0.8$ & $472.41 \mu \mathrm{g} / \mathrm{g} \pm 0.9$ \\
\hline Brix & $9.27 \pm 0.06$ & $11.90 \pm 0.10$ & $1.5 \pm 0.0$ \\
\hline CDO & $96000 \mathrm{mgO}_{2} / \mathrm{L}$ & $128000 \mathrm{mgO}_{2} / \mathrm{L}$ & $20800 \mathrm{mgO}_{2} / \mathrm{L}$ \\
\hline DBO & $18130 \mathrm{mgO}_{2} / \mathrm{L}$ & $18005.5 \mathrm{mgO}_{2} / \mathrm{L}$ & $18106 \mathrm{mgO}_{2} / \mathrm{L}$ \\
\hline Total solids & $86055 \mathrm{mg} / \mathrm{L}$ & $117877.5 \mathrm{mg} / \mathrm{L}$ & $6420 \mathrm{mg} / \mathrm{L}$ \\
\hline Fixed solids & $11500 \mathrm{mg} / \mathrm{L}$ & $6980 \mathrm{mg} / \mathrm{L}$ & $2372.5 \mathrm{mg} / \mathrm{L}$ \\
\hline Volatile solids & $74555 \mathrm{mg} / \mathrm{L}$ & $110897.5 \mathrm{mg} / \mathrm{L}$ & $4047.5 \mathrm{mg} / \mathrm{L}$ \\
\hline
\end{tabular}

Table 2. Summary of the analysis of variance of different species of fungi present in seeds of fava accessions, after treatments with organic by-products.

\begin{tabular}{|c|c|c|c|c|c|c|}
\hline Source/variation & Df & $\begin{array}{l}\text { Aspergillus } \\
\text { niger }\end{array}$ & $\begin{array}{l}\text { Aspergillus } \\
\text { flavus }\end{array}$ & Penicillium sp & $\begin{array}{l}\text { Penicillium } \\
\text { variable }\end{array}$ & $\begin{array}{l}\text { Fusarium } \\
\text { verticillioides }\end{array}$ \\
\hline Accessions & 1 & $24.64 * *$ & $0.41 \mathrm{~ns}$ & $0.66 n s$ & $11.93^{* *}$ & $0.20 \mathrm{~ns}$ \\
\hline Products & 7 & $122.77 * *$ & $28.08 * *$ & $6.90 * *$ & $46.00 * *$ & $9.85^{* *}$ \\
\hline Accessions * Products & 6 & $53.73 * *$ & $7.63^{* *}$ & $1.69 * *$ & $3.01 * *$ & $2.41^{* *}$ \\
\hline Residue & 48 & 2.19 & 0.64 & 0.18 & 0.41 & 0.27 \\
\hline CV (\%) & & 27.17 & 34.06 & 34.13 & 35.05 & 33.95 \\
\hline
\end{tabular}

${ }^{\mathrm{ns}}$ and ${ }^{* *}$ : not significant and significant at $1 \%$, by the $\mathrm{F}$ test; Df: degree of freedom.

Table 3. Incidence of pathogens in red fava (RF) and white fava (WF) seeds after treatments with organic by-products.

\begin{tabular}{|c|c|c|c|c|c|c|c|c|}
\hline \multirow{2}{*}{ Accessions } & \multicolumn{8}{|c|}{ Treatments (Organic by-Products) } \\
\hline & T1 & $\mathrm{T} 2$ & T3 & T4 & T5 & T6 & $\mathrm{T7}$ & T8 \\
\hline & \multicolumn{8}{|c|}{ Aspergillus niger } \\
\hline RF & $107.0 \mathrm{aA}$ & $20.5 \mathrm{aC}$ & $15.0 \mathrm{aC}$ & $46.0 \mathrm{aB}$ & $32.5 \mathrm{bB}$ & $1.5 \mathrm{aD}$ & $32.5 \mathrm{aB}$ & $89 \mathrm{aA}$ \\
\hline \multirow[t]{2}{*}{ WF } & $90.2 \mathrm{aA}$ & $6.0 \mathrm{bB}$ & $7.5 \mathrm{aB}$ & $9.5 \mathrm{bB}$ & $77.5 \mathrm{aA}$ & $5.5 \mathrm{aB}$ & $10.5 \mathrm{bB}$ & $67 \mathrm{bA}$ \\
\hline & \multicolumn{8}{|c|}{ Aspergillus flavus } \\
\hline RF & $23.5 \mathrm{aA}$ & $1.5 \mathrm{aD}$ & $7.5 \mathrm{aC}$ & $13.0 \mathrm{aB}$ & $0.0 \mathrm{bD}$ & $0.0 \mathrm{aD}$ & $6.5 \mathrm{aC}$ & $4.0 \mathrm{bC}$ \\
\hline \multirow[t]{2}{*}{ WF } & $22.5 \mathrm{aA}$ & $0.5 \mathrm{aD}$ & $0.0 \mathrm{bD}$ & $7.5 \mathrm{bC}$ & $9.0 \mathrm{aB}$ & $0.0 \mathrm{aD}$ & $3.0 \mathrm{bc}$ & $8.5 \mathrm{aB}$ \\
\hline & \multicolumn{8}{|c|}{ Penicillium sp } \\
\hline RF & $3.5 \mathrm{bA}$ & $0.0 \mathrm{aB}$ & $0.0 \mathrm{aB}$ & $0.0 \mathrm{aB}$ & $0.0 \mathrm{aB}$ & $0.0 \mathrm{aB}$ & $0.0 \mathrm{aB}$ & $2.0 \mathrm{aA}$ \\
\hline \multirow[t]{2}{*}{ WF } & $12.5 \mathrm{aA}$ & $0.5 \mathrm{aB}$ & $0.0 \mathrm{aB}$ & $0.0 \mathrm{aB}$ & $0.0 \mathrm{aB}$ & $0.0 \mathrm{aB}$ & $0.0 \mathrm{aB}$ & $0.0 \mathrm{bB}$ \\
\hline & \multicolumn{8}{|c|}{ Penicillium variable } \\
\hline RF & $20.5 \mathrm{bA}$ & $2.0 \mathrm{aB}$ & $0.0 \mathrm{bC}$ & $2.0 \mathrm{aB}$ & $0.0 \mathrm{aC}$ & $0.0 \mathrm{aC}$ & $0.0 \mathrm{aC}$ & $0.0 \mathrm{bC}$ \\
\hline \multirow[t]{2}{*}{ WF } & $43.5 \mathrm{aA}$ & $3.0 \mathrm{aB}$ & $2.5 \mathrm{aB}$ & $2.0 \mathrm{aB}$ & $0.0 \mathrm{aC}$ & $0.0 \mathrm{aC}$ & $0.0 \mathrm{aC}$ & $4.5 \mathrm{aB}$ \\
\hline & \multicolumn{8}{|c|}{ Fusarium verticillioides } \\
\hline RF & $3.5 \mathrm{bB}$ & $1.0 \mathrm{aC}$ & $0.5 \mathrm{aC}$ & $8.5 \mathrm{aA}$ & $2.5 \mathrm{aB}$ & $1.0 \mathrm{aC}$ & $0.0 \mathrm{aC}$ & $0.5 \mathrm{aC}$ \\
\hline WF & $11.5 \mathrm{aA}$ & $0.0 \mathrm{aC}$ & $0.0 \mathrm{aC}$ & $4.0 \mathrm{bB}$ & $1.0 \mathrm{aC}$ & $0.0 \mathrm{aC}$ & $0.5 \mathrm{aC}$ & $0.0 \mathrm{aC}$ \\
\hline
\end{tabular}

Table 4. Summary of variance analysis for physiological variables: germination (G), first count (FC); Radicle Length (RL) and germination Velocity Index (IVG) for seeds of Fava accessions subjected to different treatments with organic by-products.

\begin{tabular}{lccccc}
\hline Source/variation & $\mathrm{Df}$ & $\mathrm{GER}(\%)$ & $\mathrm{FC}(\%)$ & $\mathrm{RL}(\mathrm{cm})$ & $\mathrm{IVG}(\%)$ \\
\hline Accessions & 1 & $1369.00^{* *}$ & $2889.06^{* *}$ & $28.29^{*}$ & $14.48^{* *}$ \\
Products & 7 & $311.68^{* *}$ & $409.49^{* *}$ & $15.09^{*}$ & $3.50^{* *}$ \\
Accessions * Products & 7 & $271.00^{* *}$ & $426.63^{* *}$ & $11.56^{*}$ & $3.23^{* *}$ \\
Residue & 48 & 41.29 & 44.65 & 5.01 & 0.35 \\
\hline CV (\%) & 7.54 & 8.43 & 20.58 & 7.09 \\
\hline ns,$* *$ and * not significant and significant at 1\%, by the F test; Df: degree of freedom
\end{tabular}


Table 5. Mean values of germination (G), first count (FC), radicle length (RL) and germination Speed Index (GCS), and for seeds of Red Fava (RF) and white Fava (WF) accessions, subjected to different treatments with by-products organic.

\begin{tabular}{|c|c|c|c|c|c|c|c|c|}
\hline \multirow[t]{2}{*}{ Accessions } & \multicolumn{8}{|c|}{ Treatments (Organic by-Products) } \\
\hline & T1 & T2 & T3 & T4 & T5 & T6 & $\mathrm{T7}$ & T8 \\
\hline & \multicolumn{8}{|c|}{ Germination - G (\%) } \\
\hline RF & $94.0 \mathrm{aA}$ & $91.0 \mathrm{aA}$ & $93.5 \mathrm{aA}$ & $81.0 \mathrm{aA}$ & $91.5 \mathrm{aA}$ & $87.0 \mathrm{aA}$ & $92.5 \mathrm{aA}$ & $88.0 \mathrm{aA}$ \\
\hline \multirow[t]{2}{*}{ WF } & $89.5 \mathrm{aA}$ & 89.5 aA & 81.5 bA & $83.0 \mathrm{aA}$ & $65.0 \mathrm{bB}$ & $88.0 \mathrm{aA}$ & $87.0 \mathrm{aA}$ & $61.0 \mathrm{bB}$ \\
\hline & \multicolumn{8}{|c|}{ First count - FC (\%) } \\
\hline RF & $90.5 \mathrm{aA}$ & 89.5 aA & 89.5 aA & $69.5 \mathrm{aB}$ & $89.0 \mathrm{aA}$ & 85.5 aA & 89.0 aA & 85.0 aA \\
\hline \multirow[t]{2}{*}{ WF } & $86.0 \mathrm{aA}$ & $81.0 \mathrm{aA}$ & 70.5 bB & $76.5 \mathrm{aB}$ & $54.0 \mathrm{bC}$ & $83.5 \mathrm{aA}$ & $75.5 \mathrm{bB}$ & $53.0 \mathrm{bC}$ \\
\hline & \multicolumn{8}{|c|}{ Radicle length - RL (cm) } \\
\hline RF & $9.04 \mathrm{aB}$ & $7.60 \mathrm{bB}$ & $12.03 \mathrm{aA}$ & $8.21 \mathrm{aB}$ & $11.54 \mathrm{aA}$ & $14.11 \mathrm{aA}$ & $9.78 \mathrm{aB}$ & $9.40 \mathrm{bB}$ \\
\hline \multirow[t]{2}{*}{ WF } & $9.38 \mathrm{aA}$ & $13.28 \mathrm{aA}$ & $12.14 \mathrm{aA}$ & $9.90 \mathrm{aA}$ & $12.23 \mathrm{aA}$ & $11.69 \mathrm{aA}$ & $10.90 \mathrm{aA}$ & $12.84 \mathrm{aA}$ \\
\hline & \multicolumn{8}{|c|}{ Germination Speed Index - GCS (\%) } \\
\hline RF & $9.33 \mathrm{aA}$ & $9.06 \mathrm{aA}$ & 9.27 aA & $7.46 \mathrm{aB}$ & $9.08 \mathrm{aA}$ & $8.67 \mathrm{aA}$ & $9.18 \mathrm{aA}$ & 8.70 aA \\
\hline WF & $8.87 \mathrm{aA}$ & $8.78 \mathrm{aA}$ & 7.95 bA & $8.18 \mathrm{aA}$ & $6.28 \mathrm{bB}$ & $8.71 \mathrm{aA}$ & $8.44 \mathrm{aA}$ & $5.95 \mathrm{bB}$ \\
\hline
\end{tabular}

T2 (Captan), T3 (agave extract), T4 (Cassava), T5 (Vinasse), T6 (agave extract + Cassava), T7 (agave extract + vinasse), T8 (Cassava + vinasse).

seeds of different species, has been used by several authors, such as Silva et al. (2008), Almeida et al. (2012) and Almeida et al. (2016), who demonstrated that in addition to providing a reduction in the microflora, also provided an increase of seeds germination.

\section{Effect of organic by-products on the physiological quality of seeds of fava}

The results concerning the evaluation of the physiological quality of fava beans seeds, showed a significant difference $(p<0.05)$ in the interaction among accessions of fava bean versus organic products for the variables: germination, first count, radicle length and speed of germination index (Table 4).

The organic byproducts behaved differently regarding the influence on the physiological characteristics of the fava beans seeds. For the red fava beans seeds, it was observed that there was no negative effect for germination, unlike what was observed in the white fava bean seeds, where treatments T5 (vinasse) and T8 (cassava wastewater + vinasse), decreased by $27.37 \%$ and $31.84 \%$, respectively. These results corroborate with Smiderle et al. (2013), where a smaller percentage of germination was found in cowpea seeds when subjected to the presence of cassava wastewater applied in the planting furrow (Table 5). Voll et al. (2010), highlight that the vinasse presents in its composition the aconitic acid, a substance that has inhibitory properties on the germination, and this effect is recorded in weeds such as wild poinsettia (Euphorbia heterophylla), morning glory (Ipomoea grandifolia), beggar tick (Bidens pilosa) and soybean (Glycine max).

In analyzes of first count, a significant difference was observed only for the treatment T4 (cassava wastewater), in red fava bean seeds, influencing negatively, with a reduction of $23.20 \%$ in this variable. The opposite was observed for white fava bean seeds, where the seeds showed higher sensitivity to the by-products, with a reduction of $18.02 \%$ in T3 (agave); $11.04 \%$ with T4 (cassava wastewater), 37.20\% with T5 (vinasse); 12.20 for T7 (agave + vinasse) and $38.37 \%$ with application of T8 (cassava wastewater + vinasse), in relation to the negative control. Moraes (2010), emphasizes that the ethanolic agave extract, can inhibit the development of some seeds, in function of the presence of saponins, substance with allelopathic properties, which is confirmed in this study when applied alone or in mixture with vinasse (Table 5).

For the radicle length $(C R)$, there was a gain of growth with the isolated application and mixtures of organic byproducts, with T3 (agave) of 58.3\%, T5 (vinasse) with $51.84 \%$ and T6 (agave + vinasse) with $85.66 \%$, in relation to the controls ( $\mathrm{T} 1$ and T2), with the red fava bean seeds. As for the seeds of white fava beans, there was no variation among the treatments. Somehow, it was observed that the by-products effects may vary negatively or positively, according to the physiological stage of the seed.

As the index of germination speed, with the exception of T4 (cassava wastewater) responsible for the reduction of $20.04 \%$, in the red fava bean, all the other treatments were statistically equal to the controls ( $\mathrm{T} 1$ and $\mathrm{T} 2$ ). Unlike the white fava bean seeds, these demonstrate greater sensitivity to treatments T5 (vinasse) and T8 (cassava wastewater+ vinasse), where it is observed a reduction between $29.19 \%$ and $32.92 \%$, respectively. According to Gonzaga (2007), the cassava wastewater may have a toxic effect on certain plants, including inhibiting the germination, due to the presence of toxic cyanogenic glycoside, however, it is of great importance with insecticide and nematicide action. Thus, it is possible that the presence of secondary metabolite has influenced the reduction of some of these variables studied, which signals the need to adapt the concentration to be employed for each intended use as an alternative.

Materials and Methods

\section{Location and experimental procedures}

The experiment was conducted in the Laboratory of Phytopathology, located in the center of Food Science and Technology, Federal University of Campina Grande, Campus of Pombal, UFCG. The geographical location is defined by the

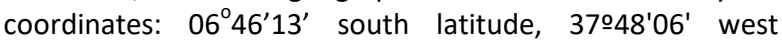
longitude and altitude of approximately $184 \mathrm{~m}$. 
In this study, two seed lots of fava bean seed (Phaseolus lunatus L.) were used of the variety known as Lavanderia Vermelha and white fava, obtained from small producers in the municipality of Cajazeiras in Paraíba-PB.

For the completion of the experiment, three organic byproducts were used, consisting of vinasse and cassava wastewater, purchased at a distillery for the production of cachaça and cassava flour mill respectively, both located in the municipality of Areia-PB. In addition to these, agave extract was also used, obtained from the leaves fibers separation, collected in the municipality of Cuité-PB. It was verified in Table 1, the physicochemical composition of organic byproducts used in this experiment.

In the assembly of the experiment, a completely randomized experimental design was used in a factorial arrangement $(8 \times 2)$, being the first factor composed of the treatments: $\mathrm{T} 1=$ sterile distilled water (negative control); $\mathrm{T} 2=$ Captan ${ }^{\circledR}$ equivalent to $1.0 \mathrm{~g} / \mathrm{kg}$ of seeds (positive control); $\mathrm{T} 3=$ extract of Agave; $\mathrm{T} 4=$ cassava wastewater; $\mathrm{T} 5=$ vinasse; $\mathrm{T} 6=$ agave extract + cassava wastewater $; 7=$ agave extract + vinasse and $T 8=$ cassava wastewater + vinasse, and for the second factor, were employed two batches of fava beans (variety as Lavanderia Vermelha and white fava), with five replications.

\section{Seed treatment}

The byproducts, vinasse, cassava wastewater and agave extract, were diluted to $50 \%$ concentration in distilled water. In the application of the treatments in the seeds, these were treated with organic byproducts isolated and with the byproducts intermixed. Thus, for the byproducts when isolated, were used $50 \mathrm{~mL}$ of each treatment for each $100 \mathrm{~g}$ of seeds, while, in the by-products mixed, corresponded to $25 \mathrm{~mL}$ of each treatment for each $100 \mathrm{~g}$ of seeds. The controls were also used: the fungicide Captan ${ }^{\circledR}(240 \mathrm{~g}$ i.a. $100 \mathrm{~kg}^{-1}$ of seeds), as recommended by the manufacturer, and the sterile distilled water, for both batches.

To achieve this, the seeds were distributed in Becker of 250 $\mathrm{mL}$, where they were immersed in each treatment (organic products), homogenized by stirring with a glass rod for 3 minutes. In the end, they were placed to dry, under controlled conditions for 20 minutes, before being subjected to incubation period.

\section{Sanitary Quality of seeds}

The evaluations were carried out for quantification and identification of the seeds microflora, as well as to the characteristics of physiological variables of the seeds. For this reason, 400 seeds were used per treatment, previously disinfected in alcohol $70 \%$ for 30 seconds and sodium hypochlorite to $1 \%$, for 3 minutes, leaving them under a temperature of $25 \pm 2{ }^{\circ} \mathrm{C}$, for drying.

Subsequently, all variables were evaluated after the application of the treatments, the highlight: the seeds microflora, using the method of incubation on paper filter (Blotter test) proposed by Neergaard (1977). For this test, 400 seeds/treatment were used (five replicates of 80 units). The seeds were incubated in Petri plates on a triple layer of filter paper, previously sterilized and moistened with sterile distilled water. The plates were kept in the incubation chamber at $20^{\circ} \mathrm{C} \pm 2^{\circ} \mathrm{C}$ and photoperiod of 12 hours, where they remained for seven days, and then to be evaluated for the presence of pathogens (Brasil, 2009). The identification and counting of fungi were performed in seeds with the aid of a stereoscopic and optical microscope. Confirmation of the fungi in the genus level was performed with the aid of an identification key (Barnett; Hunter, 1998), and then calculated the percentages of contaminated seeds.

\section{Physiological quality of seeds}

For the germination test, 200 seeds were used $(5$ replicates of 40 seeds for each treatment, distributed in germitest paper, previously sterilized and moistened with distilled water, in the amount equivalent to 2.5 times of the mass of the dry paper. Then, the rolls with 200 seeds were maintained in a germination chamber set at a constant temperature of $25^{\circ} \mathrm{C}$ under alternating photoperiod of $12 \mathrm{~h}$. The counts were performed at the 3rd and 9th day after incubation, considering the germinated seeds, which show the root system with at least $2 \mathrm{~cm}$ in length (Brazil, 2009).

As the first count of germination, it was carried out jointly with the germination test, where the counts of normal seedlings were determined on the fifth day after the testes installation. To the radicle length, the test was conducted on germitest paper, using 200 seeds, after the ninth day, the normal seedlings obtained were measured with the aid of a graduated ruler.

As for the index of germination speed of seedlings in sand the same numbers of seeds per repetition was used, where they were sown in plastic trays containing washed and sterile sand, and moisturized daily, kept in a greenhouse for a period of nine days (Alves et al. 2014). This variable was represented by the number of emerged plants daily until the ninth day after installation. The evaluations of normal seedlings were performed daily, always in the morning schedule, from the first count of germination. The result was calculated according to the formula proposed by Maguire (1962) where the number of germinated seeds or seedlings was divided by the day of counting: IVG $=G_{1} / N_{1}+G_{2} / N_{2}+\ldots$ $\mathrm{G}_{\mathrm{n}} / \mathrm{N}_{\mathrm{n}}$

where:

$\mathrm{G}_{1}, \mathrm{G}_{2}, \ldots \mathrm{G}_{\mathrm{n}}=$ number of sprouted diaspores

$N_{1}, N_{2}, \ldots N_{n}$ = number of days after sowing.

The data were subjected to analysis of variance for diagnosis of significant effects through the "F" test and when verified significant effect, the means were grouped by Scott-Knott test at $5 \%$ probability.

\section{Conclusion}

All organic by-products have potentiality in the reduction of fungi found in the two plots of bean seeds. The T6 treatment (agave extract + Cassava) has lower sensitivity in the physiological development of the seeds. The treatments submitted to the Vinasse and Cassava by-products negatively interfere with seed vigor. Red fava seeds are more tolerant to organic by-products.

\section{References}

Almeida FA, Fonseca WL, Leite MLT, Rambo TP, Pereira FF, Petter FA, Oliveira AM, Carvalho RM, Neto FA (2016) 
Toxicity of plant extracts to Meloidogyne incognita in tomato plants. Int J Curr Res. 9:38476-38481.

Almeida FA, Petter FA, Siqueira VC, Alcântara Neto F, Alves AU, Leite MLT (2012) Modos de preparo de extratos vegetais sobre Meloidogyne javanica no tomateiro. Nematropica. 43(1):9-15.

Alves AU, Cardoso EA; Alixandre TF, Cavalcante ÍHL. Beckmann-Cavalcante, MZ (2014) Emergência de plântulas de fava em função de posições e profundidades de semeadura. Biosci J. 30(1):33-42.

Araújo AV, Sales NLP, Ferreira ICPV, Brandão Junior D, Martins ER (2009) Germinação, vigor e sanidade de sementes de fava d'anta (Dimorphandra mollis Benth.) obtidas de frutos coletados no solo e na planta. Rev Bras PI Med. 11(2):170-175.

Barnett HL, Hunter BB (1998) Illustrated genera of imperfect fungi. 4. Ed. The Americam Phythological Society: Saint Paul, 218 p.

Botura MB, Santos JDG, Silva GD, Lima HG, Oliveira JVA, Almeida, MAO, Batatinha MJM, Branco A (2013) In vitro ovicidal and larvicidal activity of Agave sisalana Perr. (sisal) on gastrointestinal nematodes of goats. Vet Parasitol. 192(1-3):211-7.

Brasil (2009) Ministério da Agricultura. Secretaria Nacional de Defesa Agropecuária. Regras para análise de sementes. Brasília: Ministério da Agricultura, Pecuária e Abastecimento, 395p.

Flávio NSDS, Sales NLP, Aquino CF, Soares EPS, Aquino LFS, Catão HCRM (2014) Qualidade sanitária e fisiológica de sementes de sorgo tratadas com extratos aquosos e óleos essenciais. Semin Cienc Agrar. 35(1):720.

Fonseca WL, Almeida FA, Leite MLT, Oliveira AM, Prochnow JT, Ramos LL, Rambo TP, Neto FA, Pereira FF, Carvalho RM (2018) Influência de manipueira sobre Meloidogyne javanica na soja. Rev Ciênc Agr. 41(1):182192.

Fonseca WL, Almeida FA, Oliveira AM, Leite MLT, Prochnow JT, Ramos LL (2016) Toxicity of manipueira to Meloidogyne incognita in soybean. Pesq Agropec Trop. 46(4): 413-420.

Gomes RSS, Nunes MC, Nascimento LC, Porcino MM (2016) Eficiência de óleos essenciais na qualidade sanitária e fisiológica em sementes de feijão-fava (Phaseolus lunatus L.). Rev Bras PI Med. 18(1):279-287.

Gonzaga AD, Ribeiro JD, Vieira MF, Alécio MR (2007) Toxidez de Três Concentrações de erva-de-rato (Palicourea marcgravii A St-Hill) e Manipueira (Manihot esculenta Crantz) em pulgão verde dos citros (Aphis spiraecola Patch) em casa de vegetação. $\mathrm{R}$ bras Bioci. 5(1):195-197.

Hart KJ, Yáñez-Ruiz DR, Duval SM, Mcewan NR, Newbold CJ (2007) Plant extracts to manipulate rumen fermentation. Anim. Feed Sci Technol. 147(1-3):8-35.

Ibge - Instituto Brasileiro de Geografia e Estatística (2017) Levantamento sistemático da produção agrícola. Pesquisa mensal de previsão e acompanhamento das safras agrícolas no ano civil Relatório de ocorrências Rio grande do Sul. Disponível em: <http://wwwagriculturarsgovbr/upload/arquivos/2017
06/09094430-Ispa-pesquisa-mensal-de-previsao-eacompanhamento-maio-2017pdf> Acesso em: 20 nov 2017.

Ibge - Instituto Brasileiro de Geografia e Estatística (2013) Produção agrícola municipal Culturas Temporárias e permanentes: fava em grãos Disponível em: $<\mathrm{ftp}$ ://ftpibgegovbr/Producao_Agricola/Producao_Agri cola_Municipal_[anual]/2013/pam2013pdf> Acesso em: 25 nov 2017

Leite MLT, Almeida FA, Fonseca WL, Oliveira AM, Prochnow JT, Pereira FF, Neto FA (2016) Effect of Vinasse in the Suppressiveness to Pratylenchus brachyurus in

Soybean. J Agric Sci. 11(1): 538-545.

Lopes EA, Ferraz S, Freitas LG, Ferreira PA, Amora DX (2005) Efeito de extratos aquosos de mucuna preta e de manjericão sobre Meloidogyne incognita e $M$ javanica Nematol Bras. 29(1):67-74.

Lopes RR, Franke LB (2010) Teste de condutividade elétrica para avaliação da qualidade fisiológica de sementes de azevém (Lolium multiflorum L). Rev Bras Sementes. 32(1):123-130.

Maguire JD (1962) Speed of germination aid in selection and evaluation for seedling emergence and vigor. Crop Sci. 2(2):176-77.

Morais MS, Araújo E, Araújo AC, Belém LF (2010) Eficiência dos extratos de alho e agave no controle de Fusarium oxysporum S. Rev Bras Agroecol. 5(2):89-98.

Neergaard P (1977) Incubation tests In: Seed Pathology London: Macmillan Press, p 839.

Parsa S, Garcia-Lemos AM, Castillo K, Ortiz V, LopezLavalle LAB, Jerom FBV (2016) Fungal endophytes in germinated seeds of the common bean, Phaseolus vulgaris. Fungal Biology. 120:783-790.

Paulino J, Zolin CA, Bertonha A, Freitas PSL, Folegatti MV (2011) Estudo exploratório do uso da vinhaça ao longo do tempo II Características da cana-de-açúcar. Rev Bras Eng Agríc Ambient. 15:244-249.

Penha JS (2014) Determinação da taxa de fecundação cruzada natural e diversidade genética em feijão-fava por marcadores microssatélites. 36p. Dissertação (Mestrado - Genética e melhoramento) Universidade Federal do Piauí, Teresina, Brasil.

Riverberi M, Ricelli A, Zlalic S, Fabbri AA, Fanelli C (2010) Natural functions of mycotoxins and control of their biosynthesis in fungi. Appl Microbiol Biotechnol. 87(3):899-911.

Santos JDG, Branco A, Silva AF, Pinheiro AG, Neto AG, Uetanabaro APT, Queiroz SROD, Osuna JTA (2009) Antimicrobial activity of Agave sisalana. Afr J Biotechnol. 8(22):6181-6184.

Silva GC, Gomes DP, Kronka AZ, Moraes MH (2008) Qualidade fisiológica e sanitária de sementes de feijoeiro (Phaseolus vulgaris L.) provenientes do estado de Goiás. Semin Cienc Agrar. 29(1):29-34.

Smiderle, OJ, Lima JE, Oliva LSC, Souza AG (2013) potencial fisiológico e produtividade de sementes de feijão caupi produzidas em residual de diferentes adubações. In: II congresso nacional de feijão-caupiCONAC, Recife. 
Tenório Z, Carvalho OS, Silva ORRF, Montes JMG, Lópes FG (2000) Estudio de la atividade biológica de dos solos de los tabuleiros costeiros del NE de Brasil enmendados com resíduos agrícolas: vinaza y torta de caña de azúcar. Rev Bras Eng. Agríc Ambient. 2:70-74.
Voll E, Gazziero DLP, Adegas FS (2010) Ácido aconítico em sementes de espécies de plantas daninhas de diferentes locais. Planta Daninha. 28(1):13-22. 